\title{
USAGE OF WOOD ASH AND GGBS IN THE PRODUCTION OF CONCRETE
}

\author{
Vasanthakumara HM', C.M Ravi Kumar ${ }^{2}$, Anusha D.M ${ }^{3}$ \\ ${ }^{1} P G$ Student, Department of Civil Engineering, UBDT College, K.A., India \\ ${ }^{2}$ Assistant Professor, Department of Civil Engineering, UBDT College, K.A., India \\ ${ }^{3} P G$ Student, Department Of Civil Engineering, UBDT College, K.A., INDIA
}

\begin{abstract}
The major problem the world is facing today is the environmental pollution. In the construction industry mainly the production of Portland cement will causes the emission of pollutants results in environmental pollution. The carbon dioxide produced by cement industries causes environmental pollution and global warming. In $1000 \mathrm{Kg}$ of cement manufacturing processes approximately $900 \mathrm{Kg}$ of $\mathrm{CO}_{2}$ is emitted. In order to reduce the impact of cement production on atmosphere, wastes by products are used as admixture in this study, so that environmental pollution and natural resources consumption is reduced.In the present study wood ash is varied up to $20 \%(5 \%, 10 \%, 15 \%$ and $20 \%)$ and GGBS is added to optimum wood ash content cement concrete from $10 \%$ to $30 \%(10 \%, 20 \%$ and 30\%).These two wastes are used as a partial replacement of cement and various properties like Compressive strength, Split tensile strength and Shear strength were determined.
\end{abstract}

Keywords: Wood ash, GGBS, Concrete, aggregates, Compressive strength, Split tensile strength, Shear strength test and Fineness modulus.

\section{INTRODUCTION}

In the recent years growing consciousness about global environment and increasing energy security has led to increasing demand for renewable energy resources sand to diversify current methods of energy production. Among these resources, biomass (forestry and agricultural wastes) is a promising source of renewable energy. In the current trends of energy production, power plants which run from biomass have low operational cost and have continuous supply of renewable fuel. It is considered that these energy resources will be the $\mathrm{CO} 2$ neutral energy resource when the consumption rate of the fuel is lower than the growth rate. Also, the usage of wastes generated from the biomass industries (sawdust, woodchips, wood bark, saw mill scraps and hard chips offer a way for their safe and efficient disposal. The thermal combustion greatly reduces the mass and the volume of the waste thus providing an environmentally safe and economically efficient way to manage the solid waste.

The most prevailing method for disposal of the ash is land filling which accounts for $70 \%$ of the ash generated, rest being either used as soil supplement (20\%) or other miscellaneous jobs (10\%). The characteristics of the ash depend upon biomass characteristics (herbaceous material, wood or bark), combustion technology (fixed bed or fluidized bed) and the location where ash is collected.

\subsection{Materials and Methodology}

\subsection{Cement}

Ordinary Portland Cement (OPC) of 43 grade with brand name Ultra-Tech confirming to IS 8112-1989 was used to cast the specimens. To know the quality of selected cement few tests have been conducted in the Laboratory.

Table 1: Test Results of Cement

\begin{tabular}{|c|c|c|c|}
\hline $\begin{array}{l}\mathrm{SL} \\
\mathrm{NO}\end{array}$ & Test & Test Results & $\begin{array}{l}\text { IS 8112-1989 } \\
\text { Requirements }\end{array}$ \\
\hline 1 & \begin{tabular}{|l|} 
Normal \\
Consistency
\end{tabular} & $32 \%$ & \\
\hline 2 & \begin{tabular}{|ll}
$\begin{array}{l}\text { Initial } \\
\text { Time }\end{array}$ & Setting \\
\end{tabular} & 36 minutes & $>30$ minutes \\
\hline 3 & Final Setting Time & 260 minutes & $<600$ minutes \\
\hline 4 & Specific Gravity & 3.11 & \\
\hline 6 & $\begin{array}{l}\text { Fineness of cement } \\
\text { ( Sieving method) }\end{array}$ & $5 \%$ & $<10 \%$ \\
\hline 7 & $\begin{array}{l}\text { Compressive } \\
\text { Strength } \\
\text { 3days strength } \\
\text { 7days strength } \\
\text { 28days strength }\end{array}$ & $\begin{array}{l}22.45 \mathrm{~N} / \mathrm{mm}^{2} \\
29.86 \mathrm{~N} / \mathrm{mm}^{2} \\
47.41 \mathrm{~N} / \mathrm{mm}^{2}\end{array}$ & $\begin{array}{ll}>16 & \mathrm{~N} / \mathrm{mm}^{2} \\
>22 & \mathrm{~N} / \mathrm{mm}^{2} \\
>43 & \mathrm{~N} / \mathrm{mm}^{2}\end{array}$ \\
\hline
\end{tabular}




\subsection{Fine Aggregate (FA)}

Locally available clean Manufactured Sand is utilized all through the experiment work. The physical properties of Fine aggregate acquired from the laboratory tests are appeared in Table 2

Table 2: Test results of Fine Aggregate

\begin{tabular}{||l|l|l||}
\hline SL NO & Test & Test Results \\
\hline 1 & Specific Gravity & 2.50 \\
\hline 2 & Water Absorption & $0.7 \%$ \\
\hline 3 & Fineness Modulus & 2.92 \\
\hline
\end{tabular}

\subsection{Coarse Aggregate (CA)}

Crushed natural-granite aggregate from local crusher has been used and which has maximum size of $20 \mathrm{~mm}$. The tests for natural granite aggregate are conducted as per IS 3831970 procedure and the obtained results are presented in Table 3.

Table 3: Test Results of Coarse Aggregate

\begin{tabular}{|l|l|l|}
\hline SL NO & Test & Test Results \\
\hline 1 & Specific gravity & 2.65 \\
\hline 3 & FM & 6.88 \\
\hline 3 & Water absorption & $0.6 \%$ \\
\hline
\end{tabular}

\subsection{Wood $\operatorname{ash}($ WA $)$}

Four different proportions of concrete mix (WA replacement of $5 \%, 10 \%, 15 \%$ and $20 \%$ by weight of the cement) including the control mixture were prepared with water to binder ratio of 0.50 . The specific gravity of wood ash is found to be approximately equal to cement. Specific gravity of wood ash is 2.31. The suitablerangeof specificgravityof woodashis 1.6 to 2.8 .

\subsection{GGBS (GGBFS)}

Ground Granulated Blast furnace Slag consist essentially silicates and alumina silicates of calcium. Portland cement is a good catalyst for activation of slag because it contains the three main chemical components that activate slag: lime, calcium sulphate and alkalis. The material has glassy structure and is ground to < than 45 microns. The surface area is about $350-450 \mathrm{~m} 2 / \mathrm{kg}$ Blaine. The ground slag in presence of water and an activator which are commonly sulphates and alkalis which are supplied by ordinary Port land Cement react chemically with GGBS and hydrates and sets in a manner similar to Portland cement. The Specific gravity of GGBS 2.91 .

\subsection{Water}

Clean fresh water is used for mixing and curing the specimens.

\subsection{Casting}

The cubes of inner dimensions $150 \mathrm{X} 150 \mathrm{X} 150 \mathrm{~mm}$ were cast to find out the Compression strength of concrete. To evaluate the split tensile strength cylinders of $150 \mathrm{~mm}$ diameter with $300 \mathrm{~mm}$ height were cast and to evaluate Shear strength 150x60x90mm moulds were used. The proportions for various mixes were evaluated for $50 \mathrm{~mm}$ slump. The mixes are designed for M20 grade concrete as per ISCodes. All materials are weighed, as in mix design separately. The cement, sand, natural-coarse aggregate. Wood ash and GGBS were dry mixed in pan mixer thoroughly till uniform mix is achieved required a quantity of water is added to the dry-mix. The fresh concrete was placed in the mould and the compaction was adopted by mechanical vibrator. The specimens were removed from moulds after 24 hours and placed in water pound for 28 days curing after a period of 28 days the specimens were taken out and allowed to dry under shade later the specimens are allowed for testing.

Table 4: Mix Proportions per Cubic Meter of concrete (W/c

\begin{tabular}{|l|l|l|l|l|}
\hline Mix & $\begin{array}{l}\text { Cement } \\
(\mathbf{k g})\end{array}$ & $\begin{array}{l}\text { FA } \\
(\mathbf{K g})\end{array}$ & $\begin{array}{l}\text { CA } \\
(\mathbf{k g})\end{array}$ & Water (ltrs) \\
\hline Conventional & 330 & 640 & 1106 & 165 \\
\hline $5 \%$ WA & 313.5 & 640 & 1106 & 165 \\
\hline $10 \%$ WA & 297 & 640 & 1106 & 165 \\
\hline $15 \%$ WA & 280.5 & 640 & 1106 & 165 \\
\hline $20 \%$ WA & 264 & 640 & 1106 & 165 \\
\hline Ratio & 1 & 1.55 & 2.74 & W/C $=0.5$ \\
\hline
\end{tabular}

\section{TESTS FOR SPECIMENS}

\subsection{Compressive Strength Test}

Thistestisconductedbyusing3000kN(CTM).Thecubewas kept in the CTM and the load is given at a constant rate of $140 \mathrm{~kg} / \mathrm{cm}^{2}$,till the specimen fails and the corresponding load noted as ultimate load. The cube compressive strength is computed by using standard formula. The obtained results are indicated in Table 5.

\subsection{Split Tensile Test}

This test is conducted by using $3000 \mathrm{kN}$ compression testing machine (CTM). The cylinder is placed at the bottom compression plate and is aligned in such a way that center 
lines marked on the ends of the specimen which are a vertical. Then the top plate of the CTM is brought in contact at the top the cylinder.Theloadappliedattheuniformrateof $140 \mathrm{~kg} / \mathrm{cm} 2$ and the failure load is noted. Strength is calculated by the splitting tensile the formula of $2 \mathrm{P} / \pi \mathrm{dl}$ and results are presented in Table 6 .

\subsection{Shear Strength Test}

Thistestisconductedbyusing3000kN(CTM). Thecubewas kept in the CTM and the load is applied at a constant rate of $140 \mathrm{~kg} / \mathrm{cm}^{2}$ the shear strength is characterized as the heap at which a protest can withstand toward a path of parallel to the substance of the material, instead of opposite to the surface. Shear strength is the most extreme shear stretch which a material can with stand without break. The cube is placed in such a manner the load is applying to the $150 * 90 * 60 \mathrm{mmmould}$ and the load at which it breaks are recorded.

\section{RESULTS AND DISCUSSION}

\subsection{Compressive Strength}

For every concrete mix, the compressive strength is determined on three $150 \times 150 \times 150 \mathrm{~mm}$ cubes at 7 days and 28 days of curing. Following table5 gives the compressive Strength test results of concrete with constant 5\%,10\%, 15\% and $20 \%$ of Wood ash and varying $10 \%, 20 \%$ and $30 \%$ of GGBS for each interval. The test results of the cube compressive strength are presented in Table 5 and Figure 1 to 4.

In this work the Compressive strength of concrete made with wood ash and GGBS. The compressive strength of partially cement replaced concrete made with5,10, 15 and $20 \%$ of wood ash and 10, 20 and $30 \%$ of GGBSrangesfrom 18.11 to $23.70 \mathrm{MPa}$ at 7 days and 30.22 to 34.52 at 28 days from the experimental results, it is clear that the compressive strength of concrete made with 10\% WA and 20\% GGBS shows higher compressive strength value than conventional concrete mix. From the results it is concluded that the WA and GGBS can lightly improve the Compressive strength of concrete. Hence it is viable to use WA up to $10 \%$ replacement and GGBS up to $20 \%$ replacement without affecting the required strength.

Table 5: Compressive Strength of Concrete

\begin{tabular}{|l|l|l|l|}
\hline SL No & $\begin{array}{l}\text { Mix(WA+GG } \\
\text { BS) \% }\end{array}$ & $\begin{array}{l}\text { Compressive Strength in } \\
\left(\mathbf{N} / \mathbf{m m}^{2}\right)\end{array}$ \\
\cline { 3 - 4 } & & $\mathbf{7 d a y s}$ & $\mathbf{2 8 d a y s}$ \\
\hline 1 & Convectional & 18.81 & 30.22 \\
\hline 2 & $5+0$ & 17.77 & 30.67 \\
\hline 3 & $10+0$ & 20.45 & 32.15 \\
\hline 4 & $15+0$ & 17.62 & 28.74 \\
\hline 5 & $20+0$ & 14.37 & 24.74 \\
\hline 6 & $5+10$ & 19.70 & 31.11 \\
\hline
\end{tabular}

\begin{tabular}{|l|l|l|l|}
\hline 7 & $5+20$ & 21.18 & 32.89 \\
\hline 8 & $5+30$ & 20.88 & 32.00 \\
\hline 9 & $10+10$ & 21.77 & 31.56 \\
\hline 10 & $10+20$ & 23.70 & 34.52 \\
\hline 11 & $10+30$ & 20.15 & 32.59 \\
\hline 12 & $15+10$ & 18.52 & 30.07 \\
\hline 13 & $15+20$ & 16.59 & 25.63 \\
\hline 14 & $15+30$ & 15.70 & 25.03 \\
\hline 15 & $20+10$ & 14.36 & 23.11 \\
\hline 16 & $20+20$ & 13.18 & 22.67 \\
\hline 17 & $20+30$ & 11.11 & 21.33 \\
\hline
\end{tabular}

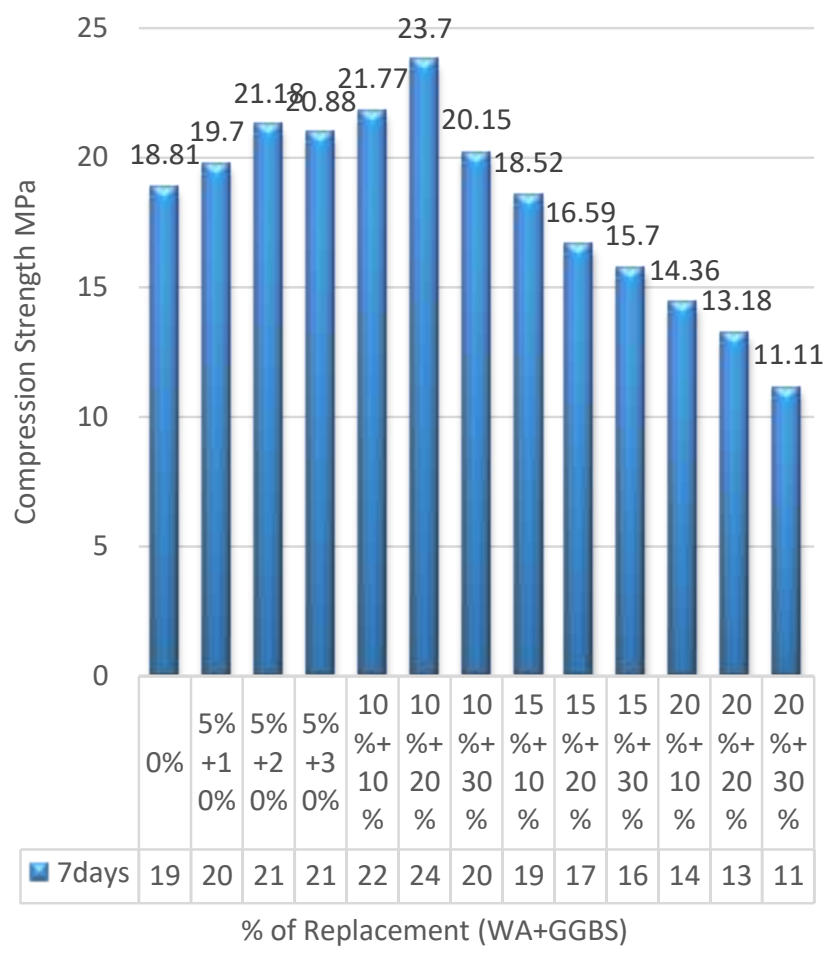

Fig 1: Compressive Strength of Concrete at 7 days

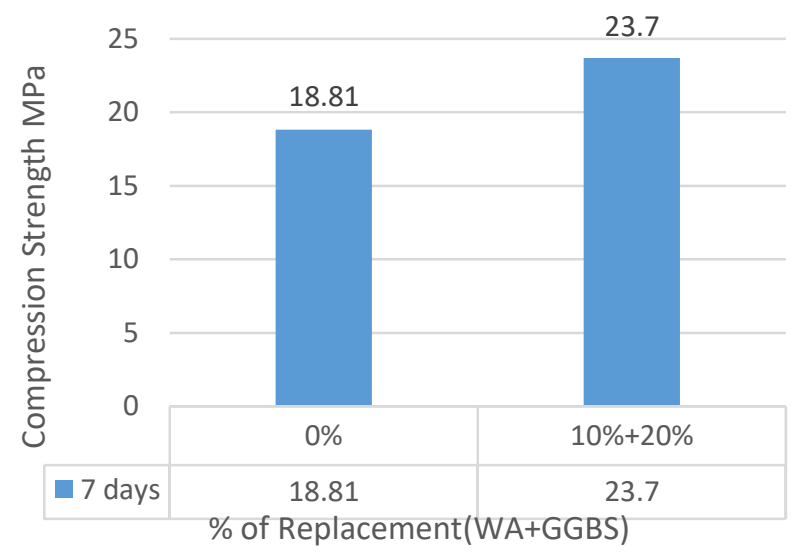

Fig 2: Comparison of Compressive Strength with Conventional Concrete at 7 days 


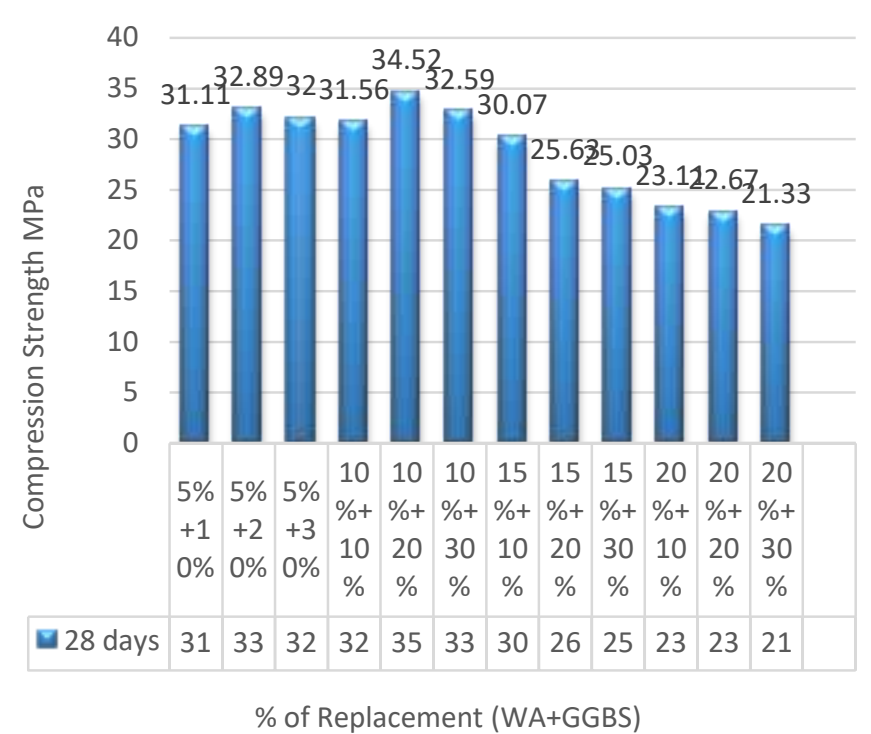

Fig 3: Compressive Strength of Concrete at 28 days

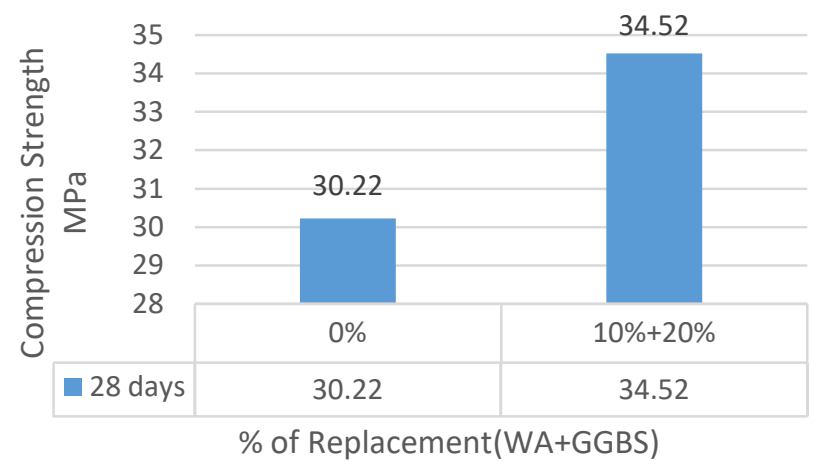

Fig 4: Comparison of Compressive Strength with Conventional Concrete at 28 days

\subsection{Split Tensile Strength Test Result}

Test has been conducted after7days and 28 days of curing. Split tensile test is conducted on $150 \mathrm{~mm}$ diameter and 300 mm length cylinders bas per IS 5816 - 1999. Following table 6 and figure 5 to 8 gives the split tensile strength resultsofconcretemadewith constant $5 \%, 10 \%, 15 \%$ and $20 \%$ of wood ash and varying $10 \%, 20 \%$ and $30 \%$ of GGBS for each interval.

In this work the Split tensile strength of concrete made with wood ash and GGBS. The Split tensile strength of partially cement replaced concrete made with 5,10,15 and 20\%Wood ash and 10, 20 and $30 \%$ of GGBSrangesfrom1.51 to2.26MPa at 7 days and 1.65 to 2.97 at 28 days. From the Experimental results it is clears that the Split tensile strength of concrete made with $10 \%$ WA and 20\% GGBS shows higher Split tensile strength value than conventional concrete mix. From the results it is concluded that the WA and GGBS can lightly improve the Split tensile strength of concrete. Hence it is viable to use WA up to10\% replacement and GGBS up to $20 \%$ replacement without affecting the required strength.
Table 6: Split Tensile Strength of Concrete

\begin{tabular}{|c|c|c|c|}
\hline \multirow[t]{2}{*}{ Sl.N0 } & \multirow{2}{*}{\begin{tabular}{|l} 
Mix \\
(WA+GGBS) \\
$\%$
\end{tabular}} & \multicolumn{2}{|c|}{$\begin{array}{l}\text { Split Tensile Strength in } \\
\left(\mathrm{N} / \mathrm{mm}^{2}\right)\end{array}$} \\
\hline & & 7days & 28days \\
\hline 1 & Convectional & 1.98 & 2.40 \\
\hline 2 & $5+0$ & 1.93 & 2.97 \\
\hline 3 & $10+0$ & 2.40 & 3.25 \\
\hline 4 & $15+0$ & 1.98 & 2.54 \\
\hline 5 & $20+0$ & 1.55 & 2.12 \\
\hline 6 & $5+10$ & 1.83 & 2.40 \\
\hline 7 & $5+20$ & 1.79 & 2.31 \\
\hline 8 & $5+30$ & 1.74 & 2.31 \\
\hline 9 & $10+10$ & 1.98 & 2.45 \\
\hline 10 & $10+20$ & 2.26 & 2.97 \\
\hline 11 & $10+30$ & 1.98 & 2.54 \\
\hline 12 & $15+10$ & 1.60 & 1.98 \\
\hline 13 & $15+20$ & 1.50 & 1.93 \\
\hline 14 & $15+30$ & 1.65 & 1.98 \\
\hline 15 & $20+10$ & 1.55 & 1.79 \\
\hline 16 & $20+20$ & 1.50 & 1.74 \\
\hline 17 & $20+30$ & 1.51 & 1.65 \\
\hline
\end{tabular}

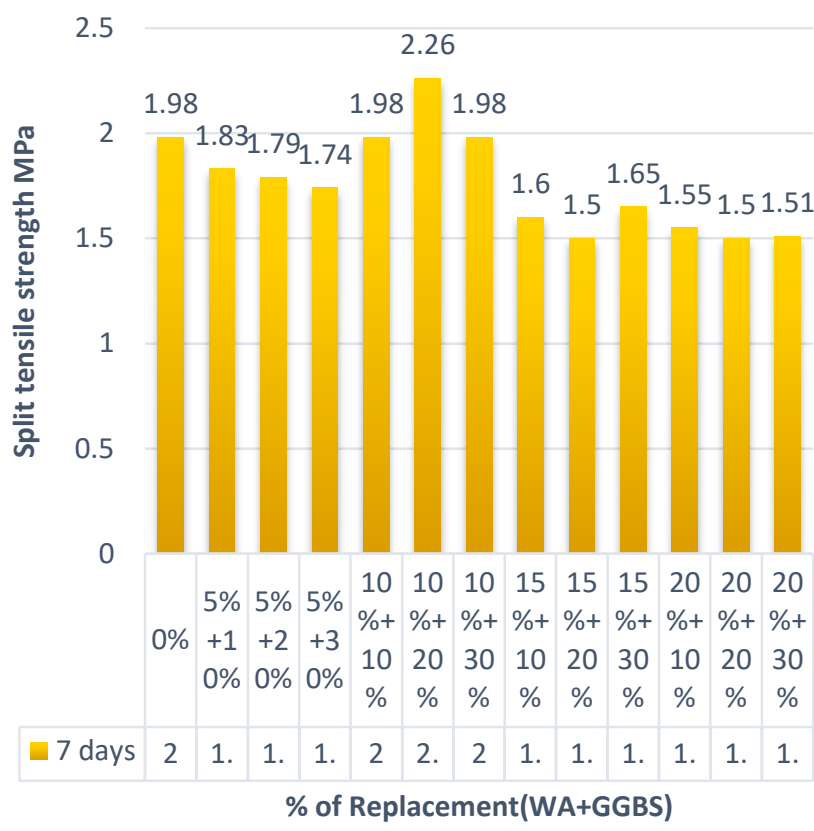

Fig 5: Split Tensile Strength of Concrete at 7 days 


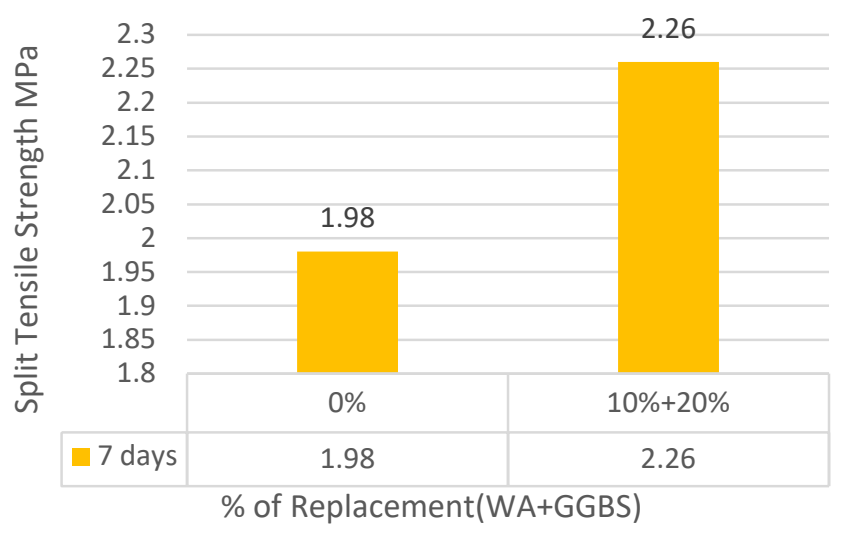

Fig 6: Comparison of Split Tensile StrengthWith conventional concrete at 7 days

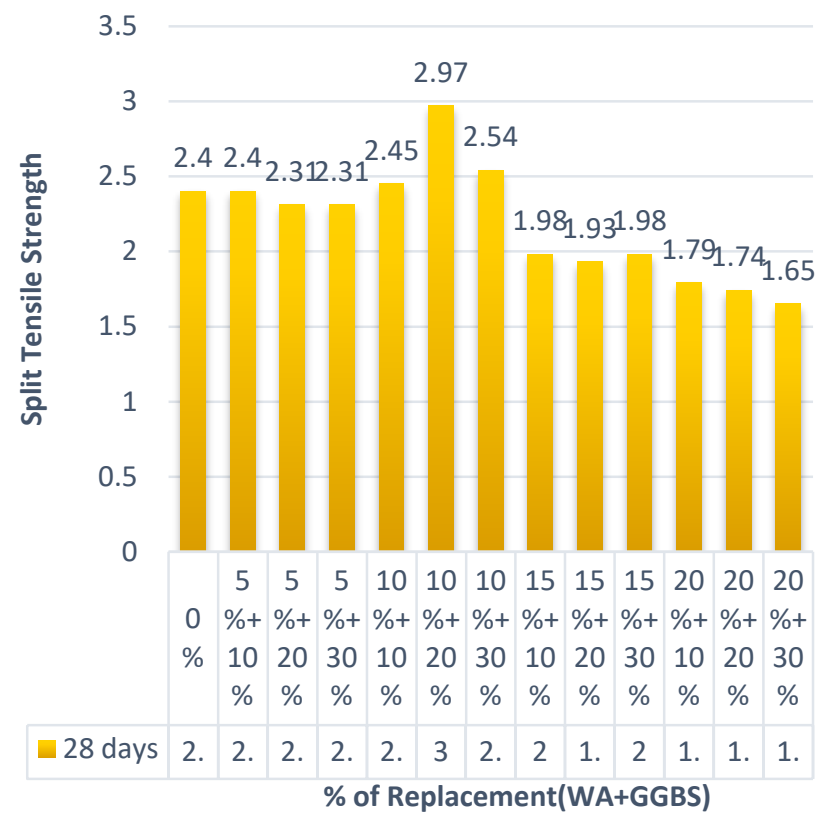

Fig 7: Split Tensile Strength of Concrete at 28 days

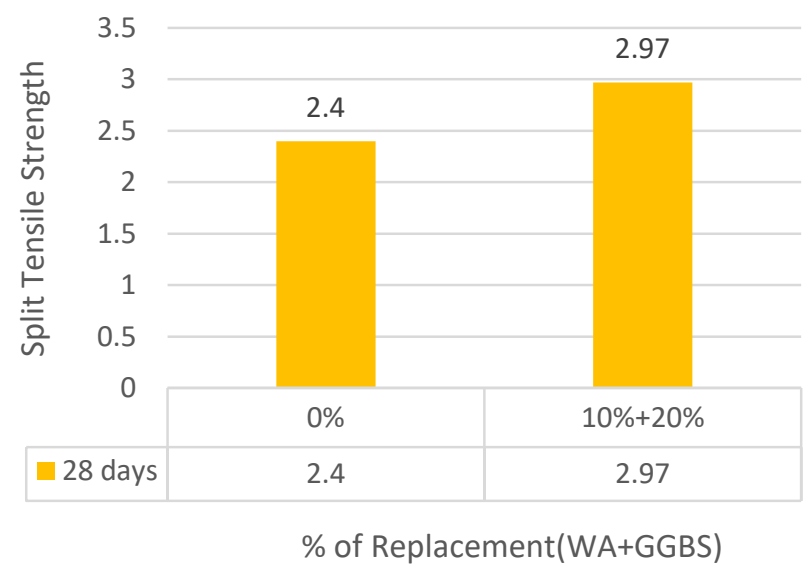

Fig 8: Comparison of Split Tensile Strength with Conventional Concrete at 28 day

\subsection{Shear Strength Test Result}

The shear strength test for concrete is additionally one of the essential and furthermore imperative properties of the concrete. The shear strength is characterized as the heap at which a protest can withstand toward a path of parallel to the substance of the material, instead of opposite to the surface

Table 7: Shear Strength of concrete

\begin{tabular}{|l|l|l|l|}
\hline \multirow{2}{*}{ Sl.No } & $\begin{array}{l}\text { Mix } \\
(\text { WA+GGB } \\
\text { S)\% }\end{array}$ & $\begin{array}{l}\text { Shear } \\
\left(\mathbf{N} / \mathbf{m m}^{2}\right)\end{array}$ & Strength in \\
\cline { 3 - 4 } & & 7days & 28days \\
\hline 1 & $\begin{array}{l}\text { Convectiona } \\
1\end{array}$ & 11.48 & 14.44 \\
\hline 2 & $5+20$ & 13.33 & 17.78 \\
\hline
\end{tabular}

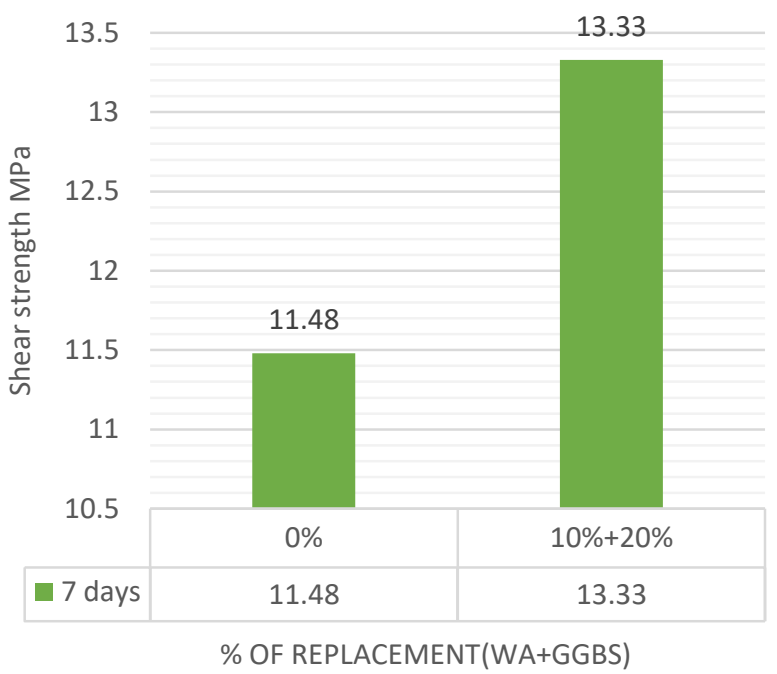

Fig 9: Comparison of Shear Strength with Conventional Concrete at 7 days



Fig 10: Comparison of Shear Strength with Conventional Concrete at 28 days 


\section{CONCLUSION}

1. The Compressive strength of conventional concreteis $18.81 \mathrm{Mpa}$ at 7 days, where as compressive strength of partially replaced cement concrete by an amount of $10 \%$ wood ash and $20 \%$ of GGBS at 7 days found to be 23.7Mpa. Also it is found that the compressive strength of partially replaced concrete have $20.63 \%$ ehigher 1 strength than 1 the conventional concrete respectively.

2. The Compressive strength of conventional concrete is $30.22 \mathrm{Mpa}$ at 28 days, whereas compressive strength of partially replaced cement concrete by an amount of $10 \%$ wood ash and $20 \%$ of GGBS at 28 days found to be $34.52 \mathrm{Mpa}$. Also it, is found that the compressive strength of partially replaced concrete have $12.45 \%$ higherstrength than 1 the conventional concrete respectively.

3. The Splittensile strength of conventional concrete is $1.98 \mathrm{Mpa}$ at 7 days, where as split tensile strength of partially replaced cement concrete by an amount of $10 \%$ wood ash and $20 \%$ of GGBS at 7 days found to be $2.26 \mathrm{Mpa}$. Also it is found that the Splittensile strength of partially replaced c0ncrete has $12.38 \%$ higher strength than the conventional concrete respectively.

4. The splittensile strength of conventional concrete is $2.40 \mathrm{Mpa}$ at 28days, where as split tensile strength of partially replaced cement concrete by an amount of $10 \%$ wood ash and $20 \%$ of GGBS at 28 days found to be $2.97 \mathrm{Mpa}$. Also it is found that the Splittensile strength of partially replaced concrete has $19.19 \%$ higher strength than1 the conventional concrete respectively.

5. The shear strength of conventional concrete is $11.48 \mathrm{Mpa}$ at 7 days, where as shear strength of partially replaced cement concrete by an amount of $10 \%$ wood ash and $20 \%$ of GGBS at 7 days found to be $13.33 \mathrm{Mpa}$. Also it is found 1that the shear strength of partially replaced concrete have $13.87 \%$ higher strength 1 than the conventional concrete respectively.

6. The shear strength of conventional concrete is $14.44 \mathrm{Mpa}$ at 28 days, where as shear strength of partially replaced cement concrete by an amount of $10 \%$ wood ash and $20 \%$ of GGBS at 28 days found to be $17.78 \mathrm{Mpa}$. Also it is found 1 that the shear strength of partially replaced concrete have $18.78 \%$ higher strength than the conventional concrete respectively.

\section{REFERENCES}

[1] Paki Turgut (2007)“Cement composites with limestone dust and different grades of wood sawdust" Department of Civil Engineering, Harran University, Osmanbey Campus, Sanliurfa, Turkey, Building and Environment 42 (2007) 3801-3807, Science direct.

[2] Cheah Chee Ban, MahyuddinRamli(2011) "The implementation of wood waste ash as a partial cement replacement material in the production of structural grade concrete and mortar"School of Housing, Building and Planning, UniversitiSains Malaysia,
11800 Penang, Malaysia Resources, Conservation and Recycling 55 (2011) 669-685.

[3] Rafat Siddique (2012) "Utilization of wood ash in concrete manufacturing" Senior Professor of Civil Engineering, Thapar University, Patiala 147004, Punjab, India, Resources, Conservation and Recycling 67 (2012) 27- 33.

[4] S. Barathan and B. Gobinath(2013)"Evaluation of wood ash as a partial replacement to cement" Volume 2, Issue 10, October 2013ISSN: 2278 7798,Department Of Physics, Annamalai University, Annamalai Nagar, Tamilnadu, India, International Journal of Science, Engineering and Technology Research (IJSETR)

[5] D. Suresh and K. Nagaraju(2015)“'Ground Granulated Blast Slag (GGBS) In Concrete - A Review"Assistant professor, Civil Engineering Department, Kuppam Engineering College, Kuppam. Chittoor district, Andhra Pradesh, e-ISSN: 22781684,p-ISSN: 2320-334X, Volume 12, Issue 4 Ver. VI (Jul. - Aug. 2015), PP 76-82 IOSR Journal of Mechanical and Civil Engineering (IOSR-JMCE)

[6] Amrutha Sebastian (2016) "Partial Replacement of Cement with Wood Ash" Volume 2 | Issue 11 | May 2016 ISSN (online): 2349-784X,Department of Civil Engineering Department of Civil Engineering,KanjirapallyIJSTE - International Journal of Science Technology and Engineering.

[7] Etaveni Madhavi1, (2016) "Evaluation of Wood Ash as Partially Replacement to Cement" Assistant Professor, Dept. of Civil Engineering, Aurora Engineering College, Bhongir, India, Vol. 5, Issue 4, April 2016, International Journal of Innovative Research in Science Engineering and Technology.

\section{IS-Codes}

[1] IS: 10262-2009, Concrete Mix Proportioning Guidelines (First Revision), Bureau Of Indian Standards, Manak The Bhavan , 9 Bahadur Shah Zafar Marg, New Delhi, July 2009.

[2] IS :456-2000, Plain And Reinforced Concrete Code Of Practice (Fourth Revision), Bureau Of Indian Standards, Manak The Bhavan, 9 bahadur Shah Zafar Marg, New Delhi, October 2000.

[3] IS:8112-1989, 43 Grade Ordinary Portland Cement Specification (First Revision), Bureau Of Indian Standards, Manak The Bhavan , 9 bahadur Shah Zafar Marg, New Delhi, May 1990.

[4] IS:383-1970 Specification For Coarse And Fine Aggregate From Natural Sources For Concrete (Second Revision ), Bureau Of Indian Standards, Manak The Bhavan, 9 bahadur Shah Zafar Marg, New Delhi , April 1971.

[5] IS :5816-1999, Spliting Tensile Strength Of Concrete Method Of Test (First Revision ), Bureau Of Indian Standards, Manak The Bhavan , 9 bahadur Shah Zafar Marg, New Delhi, July 1999. 
IJRET: International Journal of Research in Engineering and TechnologyeISSN: 2319-1163 | pISSN: 2321-7308

https://doi.org/10.15623/ijret.2018.0701001Received: dd-Mon-Year, Accepted: dd-Mon-Year, Published: dd-Mon-Year

[6] IS:516-1959,Methods Of Test For Strenth Of Concrete, Edition 1.2, Bureau Of Indian Standards, Manak The Bhavan, 9bahadur Shah Zafar Marg, New Delhi , Reaffirmed 1999.

[7] IS:2386-1963, ( PART 3) Methods Of Test For Aggregate For Concrete, Bureau Of Indian Standards, Manak The Bhavan , 9 bahadur Shah Zafar Marg, New Delhi , Reaffirmed 1997. 